\title{
Soil microbial properties and temporal stability in degraded and restored lands of Northeast Brazil
}

\author{
Ademir Sérgio Ferreira Araújo ${ }^{\mathrm{a}, *}$, Simone Cesarz ${ }^{\mathrm{b}}$, Luiz Fernando Carvalho Leite ${ }^{\mathrm{c}}$, \\ Clóvis Daniel Borges ${ }^{\mathrm{d}}$, Siu Mui Tsai ${ }^{\mathrm{d}}$, Nico Eisenhauer ${ }^{\mathrm{b}}$ \\ ${ }^{a}$ Soil Quality Lab., Agricultural Science Center, Federal University of Piauí, Teresina, PI, Brazil \\ ${ }^{\mathrm{b}}$ Institute of Ecology, Friedrich-Schiller-University Jena, Dornburger Str. 159, 07743 Jena, Germany \\ ${ }^{\mathrm{c}}$ Embrapa Mid-North, Av. Duque de Caxias, Teresina, PI, Brazil \\ ${ }^{\mathrm{d}}$ Center of Nuclear Energy in Agriculture, University of São Paulo, Piracicaba, SP, Brazil
}

\section{A R T I C L E I N F O}

\section{Article history:}

Received 19 February 2013

Received in revised form

17 July 2013

Accepted 21 July 2013

Available online 1 August 2013

\section{Keywords:}

Soil microbial biomass

Soil enzymes

Soil fertility

Soil nutrients

Restoration practices

Tropical soil

\begin{abstract}
A B S T R A C T
Human activities, such as land use change, cause severe land degradation in many ecosystems around the globe with potential impacts on soil processes. Restoration practices aim at reverting such impacts and reconstituting the biotic composition and functioning of an ecosystem to its initial condition. The aim of this study was to monitor soil microbial properties in degraded lands in Northeast Brazil and to compare those with land under restoration. Soil samplings were conducted in 2009, 2010 and 2011 in two different seasons (wet and dry season) at sites differing in degradation status: native vegetation (NAT), moderately degraded land (MDL), highly degraded land (HDL), and land under restoration for four years (RES). Soil microbial properties showed pronounced fluctuations between seasons with higher levels of functioning in the wet than in the dry season. Soil microbial biomass and enzymes had significantly higher values under native vegetation than in degraded land, while restored land mostly corresponded to native vegetation. Soil microbial biomass, respiratory quotient and enzyme activities were more strongly affected by land degradation than soil chemical properties. Soil microbial properties varied more between seasons and years in highly degraded land than under native vegetation suggesting a buffering effect of the native vegetation on soil microbial processes. However, land degradation effects on soil microbial properties were significant in both seasons. Moreover, our results indicate that the land restoration practice applied here shifted soil microbial community composition as indicated by soil microbial stoichiometry. Our results indicate that land degradation strongly deteriorates soil microbial properties and their stability in time, but that land restoration practices likely are successful in promoting the recovery of some soil microbial functions, even after only four years. However, shifts in soil microbial community composition in restored lands may have significant feedback effects on element cycles.
\end{abstract}

(c) 2013 Elsevier Ltd. All rights reserved.

\section{Introduction}

The improper use of soil and water has promoted the emergence of large areas of degraded lands in various regions of the world, especially in Africa and Latin America (Abraham and Torres, 2007). Land degradation causes the reduction of biological productivity and affects the environmental, social and economic sustainability (Nunes et al., 2012). Especially, in the semi-arid region of Northeast Brazil, slash-and-burn practices combined with diamond-mining activities caused land degradation (Almeida-Filho and Carvalho, 2010). In addition, in this region, high temperatures and

\footnotetext{
* Corresponding author. Tel.: +55 863215 5740; fax: +55 8632155743.

E-mail address: asfaruaj@yahoo.com.br (A.S.F. Araújo).
}

evapotranspiration associated with a short rainy period with high precipitation and fragile soils intensify the effects of anthropogenic land degradation.

The Brazilian Government has invested about one million dollars in this region for the purpose of recovery of degraded land. The main goal is to restore soil properties and increase the vegetation cover as important strategies for the recovery of soil productivity and sustainability (SEMAR, 2010). The restoration process involves the use of conservation practices, such as building terraces for water storage and the sowing of plant species, such as grasses and legumes. Previous studies found increasing vegetation cover to improve the chemical and physical properties of soils (Veloso et al., 2010) as well as soil microbial biomass and enzyme activity (Nunes et al., 2012). It remains however unexplored how land degradation as well as restoration influence soil microbial properties in different 
years and seasons. Given that severe precipitation events occur alongside long dry periods, it is likely that land degradation induces large variations in soil microbial functions and reduces their stability.

Soil microbial biomass is the living component of soil organic matter (SOM) (Jenkinson and Ladd, 1981) and can be seen as an ecological attribute to assess changes in soil properties caused by crops or forest devastation (Zimmermann and Frey, 2002; Lopes et al., 2011). Moreover, soil microorganisms produce a large array of enzymes which play essential roles in various ecosystem processes and are involved in the cellular metabolism, such as the decomposition of organic materials (Van der Heijden et al., 2008; Silva et al., 2012). Soil enzyme activity is one of the first soil properties that is altered when the soils get disturbed (AcostaMartınez et al., 2007). Thus, soil enzyme activity has long been considered an indicator of soil quality because it controls both the supply of nutrients to plants and microbial growth (Burns, 1978; Burns et al., 2013).

The number of studies investigating the consequences of land degradation is increasing because of its importance on world food security and environmental quality. It is well known that land degradation decreases soil fertility as a result of loss of soil organic matter and nutrients (Lal, 1996) and reduces soil microbial biomass and activity (Nunes et al., 2012). Indeed, some previous studies in degraded lands from tropical regions showed decreased soil microbial biomass and activity in the short-term after slash-and-burn practices in the Eastern Amazonia (Denich et al., 2004) and Northeastern Semi Arid regions (Nunes et al., 2012) of Brazil. However, restoration practices, such as improving of soil properties and increasing of vegetation cover, may be a promising approach for the restoration of soil productivity and sustainability (Cooke and Johnson, 2002). Also, land restoration can shift the biological status once that microbial biomass changes being associated with alterations in ecosystem function (Potthoff et al., 2006) such as organic matter decomposition. However, there is limited knowledge of how soil microbial properties develop in time after starting agricultural and mechanical restoration practices like sowing of plant species and the building of terraces for water storage and avoiding soil erosion. In the USA, for instance, some restoration practices focus on the use of agricultural techniques, such as tillage and herbicide application to control exotic annuals before seeding with native perennials with strong effects on soil microbial communities (Potthoff et al., 2006). Thus, it is unclear how land degradation and restoration influence soil microbial properties and their variability in/among different seasons and years. Also, it is unknown if and how such treatments influence soil microbial element ratios. Specifically, we hypothesized that (1) land degradation decreases soil microbial properties (Nunes et al., 2012) and their stability, and (2) land restoration to recover soil microbial properties and their stability.

\section{Materials and methods}

The study was conducted at Gilbues (09 $49^{\prime} 55^{\prime \prime} \mathrm{S}$ and $45^{\circ} 20^{\prime}$ $\left.38^{\prime \prime} \mathrm{W}\right)$, Northeast Brazil. The climate is tropical dry with a mean precipitation of $1000 \mathrm{~mm} \mathrm{yr}^{-1}$ (with rainfall from January through May) and an annual mean temperature of $35^{\circ} \mathrm{C}$, with minimum and maximum temperatures of $22^{\circ} \mathrm{C}$ and $40^{\circ} \mathrm{C}$, respectively. According with Brazilian Soil Survey (Embrapa, 1986), the dominant soils are classified as Eutrophic Red-Yellow Podzolic soils with granite and gneiss as parental material.

The following four selected sites were studied: native vegetation (NAT), moderately degraded land (MDL), highly degraded land (HDL) and land under restoration (RES) (Table 1). The sites were very similar in soil type and climate (see above). At each site, we sampled four sub-sites (at each sub-site we randomly sampled 10 soil cores to cover some spatial heterogeneity), with each one covering an area of $\sim 1000 \mathrm{~m}^{2}$. The native vegetation is covered by trees, dominated by Cenostigma macrophyllum, Tabebuia serratifolia, Hymenaea courbaril, Orbignya phalerata, Combretum leprosum, Guarea kunthiana and Lecythis pisonis. These trees cover between 80 and $90 \%$ of the ground surface and contribute approximately with $1 \mathrm{~kg} \mathrm{~m}^{-2}$ of plant litter annually.

The MDL and HDL sites resulted from cutting of native vegetation for charcoal production in 2008 and 2004, respectively. Nowadays, the MDL site is dominated by herbaceous plant species (Aristida sepfolia, Cyperus uncynulatus and Tragus berteronianus) that cover approximately $24 \%$ of the soil surface, while that the HDE site has sparse vegetation cover $(<5 \%)$. The land restoration at RES started in 2006 by shifting the degraded land by building terraces (approximately $500 \mathrm{~m}^{2}$ ) for water storage and by applying fertilizer with 50,200 and $100 \mathrm{~kg} \mathrm{ha}^{-1}$ of $\mathrm{N}$ (urea), $\mathrm{P}_{2} \mathrm{O}_{5}$ (super single phosphate) and $\mathrm{K}_{2} \mathrm{O}$ (potassium chloride), respectively. The fertilizers were applied annually spread on the soil surface. Afterward, the RES site was re-vegetated with the herbs Crotalaria juncea and Panicum maximum at densities of 2500 and 3000 plants ha ${ }^{-1}$, respectively. The annual input of litter (air-dry) from green manure is approximately $1.5 \mathrm{~kg} \mathrm{~m}^{-2}$ on the soil surface.

Soil samples were collected at 0-10 cm depth in March (wet season) and September (dry season) of 2009, 2010 and 2011. At each site, the plant cover was carefully removed from the soil surface and soil cores $(2.5 \mathrm{~cm}$ diameter) were taken randomly. All samples were immediately stored in sealed plastic bags in a cooler and transported to the laboratory. The field-moist samples were sieved (2-mm mesh) and stored in sealed plastic bags at $4{ }^{\circ} \mathrm{C}$ for microbial analyses.

Subsamples of the soils were ground and passed through a 0.21 $\mathrm{mm}$ sieve to evaluate chemical properties (Table 2). Soil pH was determined in a 1:2.5 soil/water extract. Exchangeable Ca was determined using extraction with $1 \mathrm{M} \mathrm{KCl}$. Available $\mathrm{P}$ and exchangeable K were extracted using Mehlich-1 extraction method and determined by colorimetry and photometry, respectively (Tedesco et al., 1995). Total organic C (TOC) was determined by the wet combustion method using a mixture of potassium dichromate and sulfuric acid under heating (Yeomans and Bremner, 1998).

\section{Table 1}

Main characteristic of the evaluated sites: native vegetation (NAT), moderately degraded land (MDL), highly degraded land (HDL), and land under restoration for four years (RES).

\begin{tabular}{lllll}
\hline Characteristic & NAT & RES & MDL & HDL \\
\hline Longitude & $45^{\circ} 20^{\prime} 42.7^{\prime \prime} \mathrm{W}$ & $45^{\circ} 20^{\prime} 32.2^{\prime \prime} \mathrm{W}$ & $45^{\circ} 20^{\prime} 41.1^{\prime \prime} \mathrm{W}$ & $45^{\circ} 20^{\prime} 29.2^{\prime \prime} \mathrm{W}$ \\
Latitude & $09^{\circ} 52^{\prime} 32.1^{\prime \prime} \mathrm{S}$ & $09^{\circ} 52^{\prime} 49.6^{\prime \prime} \mathrm{S}$ & $09^{\circ} 52^{\prime} 33.0^{\prime \prime} \mathrm{S}$ & $09^{\circ} 52^{\prime} 48.3^{\prime \prime} \mathrm{S}$ \\
Altitude (m) & 441 & 449 & 460 & 452 \\
Slope $(\%)$ & $2-5$ & $5-9$ & $5-9$ & $5-9$ \\
Vegetation & Trees $^{\mathrm{a}}$ & Herbs & Herbs & $\mathrm{Herbs}^{\mathrm{c}}$ \\
Clay $\left(\mathrm{g} \mathrm{kg}^{-1}\right)$ & 510.2 & 510.8 & 500.4 & 520.1 \\
Silt $\left(\mathrm{g} \mathrm{kg}^{-1}\right)$ & 90.7 & 100.3 & 100.5 & 90.8 \\
Sand $\left(\mathrm{g} \mathrm{kg}^{-1}\right)$ & 390.1 & 370.9 & 390.1 & 380.1 \\
$\mathrm{SBD}^{\mathrm{e}}\left(\mathrm{g} \mathrm{cm}^{-3}\right)$ & 1.15 & 1.23 & 1.38 & 1.40 \\
$\mathrm{SOM}^{\mathrm{f}}\left(\mathrm{g} \mathrm{kg}^{-1}\right)$ & 22.6 & 10.4 & 5.8 & 2.1 \\
Vegetation $^{\mathrm{b}}$ & 100 & 100 & 24 & 4
\end{tabular}

a Tree species: Cenostigma macrophyllum L., Tabebuia serratifolia L., Hymenaed courbaril L., Orbignya phalerata L., Combretum leprosum L., Guarea kunthiana L. and Lecythis pisonis L.).

b Crotalaria juncea L. and Panicum maximum L.

c Aristida sepfolia L., Cyperus uncynulatus L. and Tragus berteronianus L.

d Herbs (Tragus berteronianus L.).

e SBD, soil bulk density.

${ }^{f}$ SOM, soil organic matter. 
Table 2

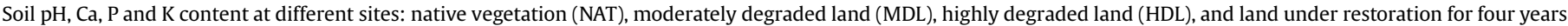
(RES).

\begin{tabular}{|c|c|c|c|c|c|c|c|c|c|c|c|c|}
\hline & \multicolumn{3}{|c|}{ Soil pH } & \multicolumn{3}{|c|}{$\mathrm{Ca}\left(\mathrm{cmol}_{\mathrm{c}} \mathrm{kg}^{-1}\right)$} & \multicolumn{3}{|c|}{$\mathrm{P}\left(\mathrm{mg} \mathrm{kg}^{-1}\right)$} & \multicolumn{3}{|c|}{$\mathrm{K}\left(\mathrm{mg} \mathrm{kg}^{-1}\right)$} \\
\hline & 2009 & 2010 & 2011 & 2009 & 2010 & 2011 & 2009 & 2010 & 2011 & 2009 & 2010 & 2011 \\
\hline NAT & $6.5^{\mathrm{b}}$ & $6.3^{c}$ & $6.7^{b}$ & $5.2^{\mathrm{d}}$ & $4.8^{\mathrm{c}}$ & $5.6^{c}$ & $13.0^{\mathrm{b}}$ & $10.3^{b}$ & $12.1^{\mathrm{b}}$ & $198^{b}$ & $180^{\mathrm{b}}$ & $175^{\mathrm{b}}$ \\
\hline RES & $7.1^{c}$ & $7.0^{\mathrm{b}}$ & $6.8^{\mathrm{b}}$ & $8.9^{c}$ & $7.2^{\mathrm{c}}$ & $7.8^{\mathrm{c}}$ & $25.1^{\mathrm{a}}$ & $22.3^{\mathrm{a}}$ & $20.4^{\mathrm{a}}$ & $234^{a}$ & $218^{a}$ & $216^{a}$ \\
\hline MDL & $7.5^{\mathrm{a}}$ & $7.3^{\mathrm{b}}$ & $7.1^{\mathrm{b}}$ & $15.4^{\mathrm{b}}$ & $14.9^{\mathrm{b}}$ & $12.1^{\mathrm{b}}$ & $11.0^{\mathrm{b}}$ & $9.5^{\mathrm{b}}$ & $10.4^{\mathrm{b}}$ & $221^{\mathrm{a}}$ & $209^{a}$ & $198^{\mathrm{a}}$ \\
\hline HDL & $7.7^{\mathrm{a}}$ & $7.8^{\mathrm{a}}$ & $8.1^{\mathrm{a}}$ & $35.2^{\mathrm{a}}$ & $37.1^{\mathrm{a}}$ & $30.5^{\mathrm{a}}$ & $6.2^{c}$ & $5.8^{c}$ & $4.3^{c}$ & $157^{c}$ & $138^{c}$ & $149^{c}$ \\
\hline
\end{tabular}

Means with different letters vary significantly (Tukey's HSD test, $P<0.05$ ).

Soil microbial biomass C (MBC) and N (MBN) were determined according to Vance et al. (1987) with extraction of $\mathrm{C}$ and $\mathrm{N}$ from fumigated and unfumigated soils by $\mathrm{K}_{2} \mathrm{SO}_{4}$. An extraction efficiency coefficient of 0.38 and 0.45 were used to convert the difference in $\mathrm{C}$ and $\mathrm{N}$ between fumigated and unfumigated soil in MBC and MBN, respectively. Hydrolysis of fluorescein diacetate (FDA) was determined according to the method of Schnurer and Rosswall (1982) and dehydrogenase activity was determined using the method described in Casida et al. (1964) based on the spectrophotometric determination of triphenyl tetrazolium formazan (TTF) released by $5 \mathrm{~g}$ of soil during $24 \mathrm{~h}$ at $35{ }^{\circ} \mathrm{C}$. Cellulase activity was estimated according to Schinner and von Mersi (1990). The $q \mathrm{CO}_{2}$ was calculated as the ratio of basal respiration to microbial biomass $C$. The $q \mathrm{CO}_{2}$ results were expressed as $\mathrm{g} \mathrm{CO}_{2}-\mathrm{C} \mathrm{d}^{-1}-\mathrm{g}^{-1} \mathrm{MBC}$. Moreover, we calculated the ratio between MBC and TOC, which is a common measure for carbon availability (e.g., Santos et al., 2012). The ratio between MBC and MBN provided information on soil microbial stoichiometry and the relative availability of carbon and nitrogen.

The results are expressed on the basis of oven-dry soil. All measurements were performed for four replicates per land degradation level and sampling time. Split-split plot analysis of variance (ANOVA) was used to test the effect of degradation level (native vegetation, moderately degraded land, highly degraded land and restored land), season (dry and rainy season, time (2009, 2010, 2011 ) and the interaction between degradation level $\times$ season on soil microbial properties (microbial biomass $C$, microbial biomass $\mathrm{N}$, microbial metabolic quotient, MBC:TOC, MBC:MBN) and enzyme activities (FDA hydrolysis, dehydrogenase, cellulase). Split-splitplot ANOVAs were performed since always the same plots were re-sampled and, therefore, data from different seasons and years represent repeated measures (split-plot approach to repeated measures analysis). Different seasons (dry and rainy) were considered as 'subplots' and different years (2009, 2010, and 2011) as 'sub-subplots' (Scheiner and Gurevitch, 2001; Eisenhauer et al., 2009).

We calculated the temporal stability of soil microbial properties as $\log _{10}$ coefficient of variance ${ }^{-1}$ (coefficient of variance $=$ standard deviation/mean $\times 100$; Eisenhauer et al., 2011) and tested treatment effects using one-factorial ANOVA. Therefore, different soil microbial variables were treated as replicates; we assumed this approach as legitimate as different soil microbial properties differed substantially in their response to land degradation and season (Fig. 1). All analyses were performed using SAS 9.3 (SAS Institute, Cary, $\mathrm{NC}$ ).
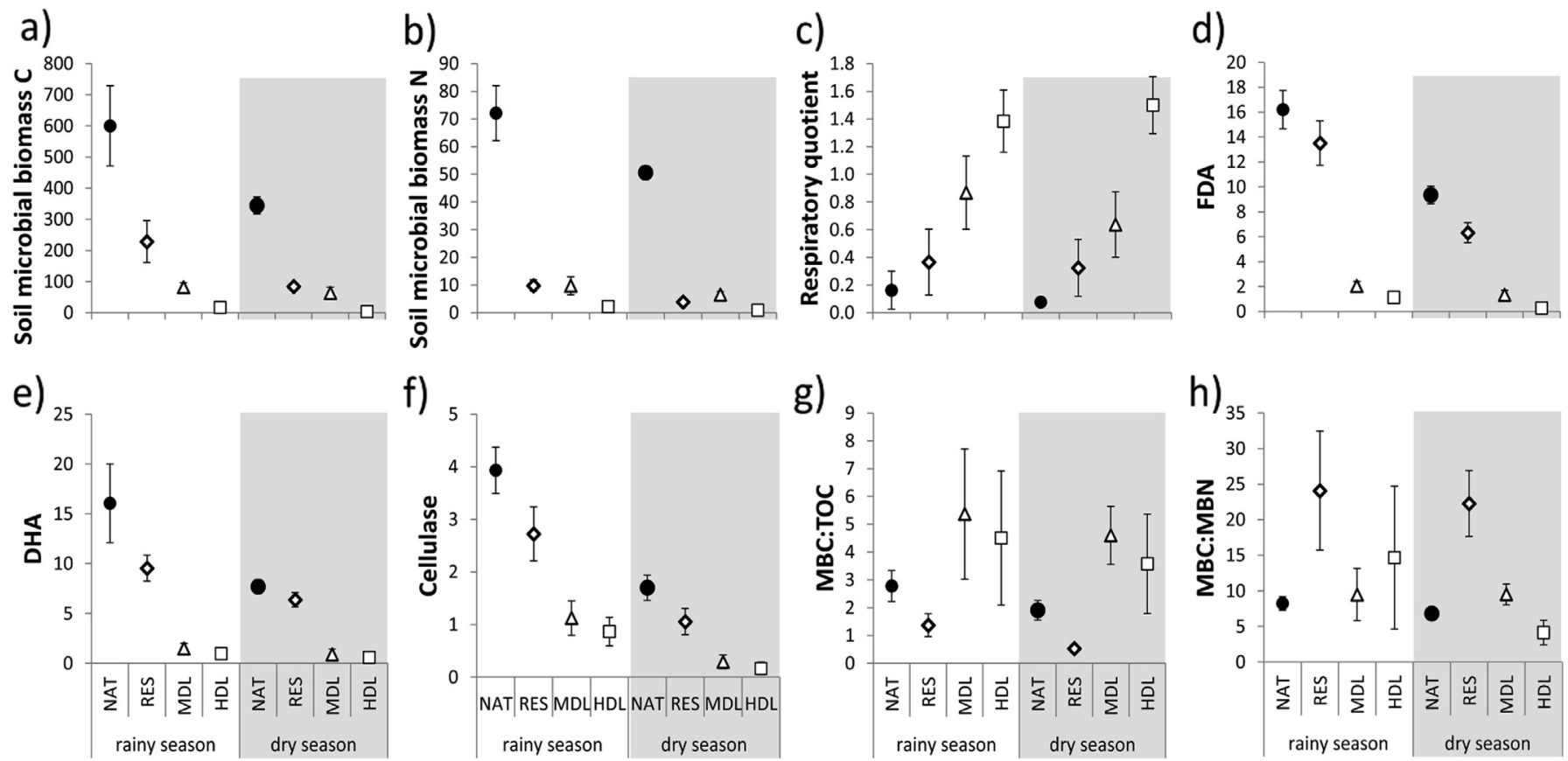

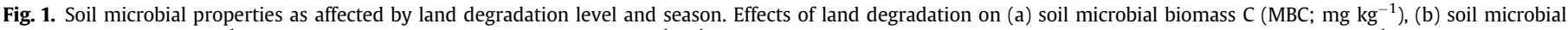

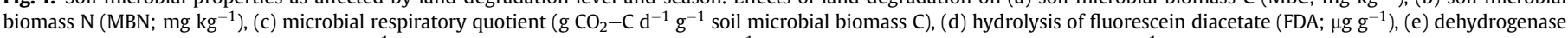

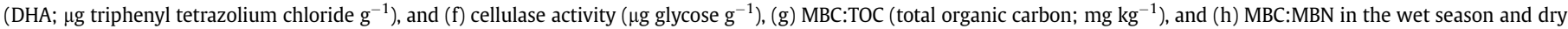

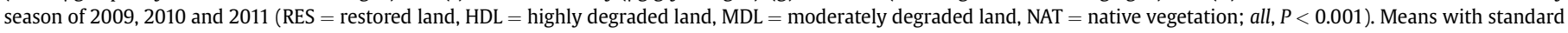
deviations. 
Table 3

Soil microbial properties in the different years (2009, 2010, and 2011; MBC: microbial biomass $\mathrm{C}$, MBN: microbial biomass $\mathrm{N}, q \mathrm{CO}_{2}$ : microbial metabolic quotient) and enzyme activities (FDA: hydrolysis of fluorescein diacetate, DHA: dehydrogenase, CEL: cellulase, TOC: total organic carbon).

\begin{tabular}{llllllllc}
\hline Year & MBC & MBN & qCO $_{2}$ & FDA & DHA & CEL & MBC:TOC & MBC:MBN \\
\hline 2009 & $148.62^{\mathrm{b}}$ & $19.09^{\mathrm{a}}$ & $0.77^{\mathrm{a}}$ & $6.02 \mathrm{~b}$ & $5.45^{\mathrm{a}}$ & $1.43^{\mathrm{a}}$ & $2.64^{\mathrm{a}}$ & $8.53^{\mathrm{b}}$ \\
2010 & $191.69^{\mathrm{a}}$ & $19.53^{\mathrm{a}}$ & $0.59^{\mathrm{b}}$ & $6.14 \mathrm{ab}$ & $5.24^{\mathrm{a}}$ & $1.52^{\mathrm{a}}$ & $3.36^{\mathrm{a}}$ & $14.63^{\mathrm{a}}$ \\
2011 & $193.13^{\mathrm{a}}$ & $19.82^{\mathrm{a}}$ & $0.63^{\mathrm{b}}$ & $6.66 \mathrm{a}$ & $5.68^{\mathrm{a}}$ & $1.50^{\mathrm{a}}$ & $3.24^{\mathrm{a}}$ & $14.07^{\mathrm{a}}$ \\
\hline
\end{tabular}

Means with different letters vary significantly (Tukey's HSD test, $P<0.05$ ).

\section{Results}

Some soil microbial properties differed between years, but they did not follow a general trend through time (Tables 3 and 4 ), which is why we focus on the effects of season below. Briefly, microbial biomass $C$ was significantly higher in 2010 and 2011 than in 2009, while microbial biomass $\mathrm{N}$ did not differ significantly between years. The respiratory quotient was significantly higher in 2009 than in 2010 and 2011. While FDA hydrolysis was significantly higher in 2011 than in 2009, dehydrogenase and cellulase activities did not differ significantly. The ratio between soil microbial $\mathrm{C}$ and total organic carbon did also not differ significantly between years, whereas the ratio between microbial biomass $C$ and microbial biomass N was significantly high in 2010 and 2011 than in 2009.

Degradation, season and interactions between degradation and season significantly influenced all soil microbial and enzyme response variables, except for the interaction effect on the ratio between soil microbial biomass $\mathrm{C}$ and total organic carbon (Table 4). Microbial biomass $\mathrm{C}$ and $\mathrm{N}$ and enzyme activities showed consistent fluctuations between seasons with higher values in the wet season than in the dry season (Fig. 1). Despite the statistically significant interaction between degradation and season (Table 4), patterns were highly consistent between seasons (Fig. 1).

All response variables - with the exception of the respiratory quotient - were significantly higher under native vegetation than in restored land (Fig. 1a-f). Also, the microbial properties were significantly higher in restored land than in degraded land (both moderately and highly degraded land). Microbial biomass $\mathrm{C}$ (Fig. 1a) and N (Fig. 1b) were significantly higher in moderately degraded land than in highly degraded land, while the respiratory quotient showed the opposite pattern (Fig. 1c). By contrast, soil enzyme activities did not differ significantly between degraded lands (Fig. 1d, e, f). The respiratory quotient was lowest under native vegetation and highest in highly degraded land with the latter indicating severe disturbance of soil microorganisms.

The ratio between soil microbial biomass $C$ and total organic carbon was significantly higher in moderately and degraded land than under native vegetation, with the latter being significantly higher than in restored land (Fig. 1g). By contrast, the ratio between soil microbial biomass $\mathrm{C}$ and microbial biomass $\mathrm{N}$ was significantly

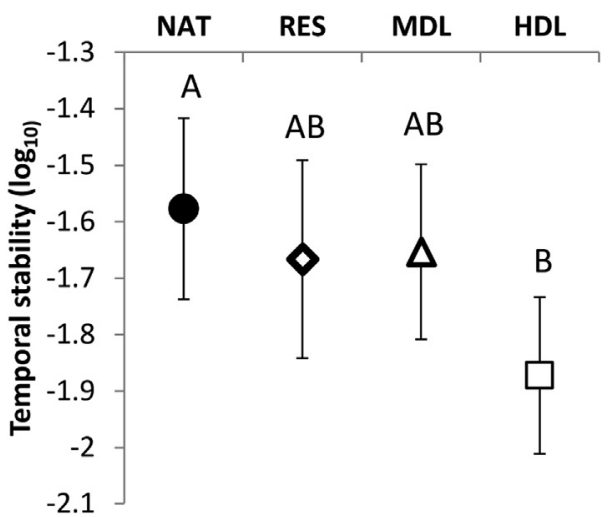

Fig. 2. Temporal stability $\left(\log _{10}\right.$ coefficient of variation $\left.{ }^{-1}\right)$ of soil microbial functions as affected by degradation level (RES $=$ restored land, HDE $=$ highly degraded land, $\mathrm{MDL}=$ moderately degraded land, NAT $=$ native vegetation; $F_{3,16}=3.2, P=0.052$ ). Bars with different letters differ significantly (Tukey HSD test, $P<0.05$ ). Means with standard deviations.

higher in restored land than under native vegetation and in degraded lands (Fig. 1h).

The stability of soil microbial properties differed marginally significantly between land degradation levels (ANOVA: $P=0.052$; Fig. 2). The stability of soil microbial properties was significantly higher under native vegetation than in highly degraded land (comparison of means with Tukey's HSD test).

\section{Discussion}

Soil microbial properties serve as a sensitive index of changes in organic matter content of the soil (Powlson et al., 1987), plant diversity loss (Zak et al., 2003; Eisenhauer et al., 2010), and disturbance (Anderson and Domsch, 1985; Bardgett and Shine, 1999; Burns et al., 2013). The present study shows that land degradation strongly deteriorates soil microbial properties, but that restoration practices may be successful in recovering some of the properties, even after only four years. The study moreover shows how consistent land degradation and restoration effects on soil microbial properties are in different seasons, with generally lower values in the dry than in the wet season. In addition, our results indicate that soil microbial biomass $\mathrm{N}$ may need much longer to recover from degradation than soil microbial $\mathrm{C}$, resulting in pronounced stoichiometric changes in soil microbial biomass. Future studies should investigate how this shift in microbial stoichiometry is associated with changes in soil microbial community composition.

The high values for soil microbial biomass and enzymes activities found under native vegetation may be attributed to the relatively high quantity and quality of plant litter supporting a larger

Table 4

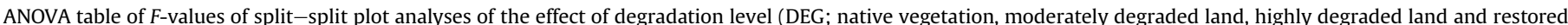

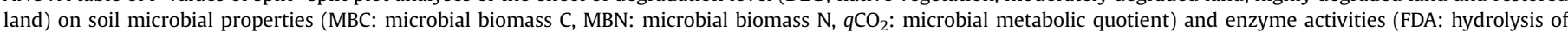
fluorescein diacetate, DHA: dehydrogenase, CEL: cellulase, TOC: total organic carbon). For detailed information on the model outputs see Supporting Data.

\begin{tabular}{|c|c|c|c|c|c|c|c|c|c|}
\hline & df & $\mathrm{MBC}$ & MBN & $\mathrm{qCO}_{2}$ & FDA & DHA & CEL & MBC:TOC & MBC:MBN \\
\hline DEG & 3 & $3848.53^{* * *}$ & $42,472.40^{* * * *}$ & $403.59^{* * *}$ & $1677.64^{* * *}$ & $4385.60^{* * *}$ & $340.86^{* * *}$ & 77.73*** & $327.94^{* * *}$ \\
\hline Plot & 12 & $0.08 \mathrm{~ns}$ & $0.02 \mathrm{~ns}$ & $0.45 \mathrm{~ns}$ & $0.57 \mathrm{~ns}$ & $0.05 \mathrm{~ns}$ & $0.78 \mathrm{~ns}$ & $0.42 \mathrm{~ns}$ & $0.16 \mathrm{~ns}$ \\
\hline Season & 1 & $359.31^{* * *}$ & $335.87^{* * *}$ & $7.64^{*}$ & $463.35^{* * *}$ & $3193.55^{* * *}$ & $490.50^{* * *}$ & $20.84^{* * *}$ & $61.69^{* * *}$ \\
\hline Season $\times$ DEG & 3 & $102.76^{* * *}$ & $111.92^{* * *}$ & $10.76^{* * *}$ & $98.55^{* * *}$ & $1130.60^{* * *}$ & $34.78^{* * *}$ & $0.03 \mathrm{~ns}$ & $30.07^{* * *}$ \\
\hline Subplot & 12 & $0.25 \mathrm{~ns}$ & $0.22 \mathrm{~ns}$ & $0.26 \mathrm{~ns}$ & $0.88 \mathrm{~ns}$ & $0.02 \mathrm{~ns}$ & $0.86 \mathrm{~ns}$ & $0.35 \mathrm{~ns}$ & $0.19 \mathrm{~ns}$ \\
\hline Year & 2 & $6.53^{* * *}$ & $0.20 \mathrm{~ns}$ & $6.84^{* * *}$ & $4.20^{*}$ & $0.45 \mathrm{~ns}$ & $0.63 \mathrm{~ns}$ & $2.02 \mathrm{~ns}$ & $15.01^{* * *}$ \\
\hline Error & 62 & & & & & & & & \\
\hline
\end{tabular}

df: degrees of freedom; ${ }^{* * *}=P<0.001,{ }^{*}=P<0.05$, ns $=$ not significant. Error terms are given in italics. 
microbial biomass and activity due to the availability of above- and belowground carbon sources (Nsabimana et al., 2004). According to previous studies, above- and belowground plant-derived $\mathrm{C}$ inputs range between 4-9 $\mathrm{t} \mathrm{ha}^{-1}$ and 30-40 $\mathrm{t} \mathrm{ha}^{-1}$ in native forests of Brazil, respectively (Freire et al., 2010; Paiva et al., 2011; Veras et al., 2010). In general, soil microbial biomass is higher in ecosystems that experience permanent inputs of organic residues as found in native forest or regenerated lands (Hackl et al., 2004; Silva et al., 2012). Relatedly, the availability of fresh organic residues under native vegetation and in restored land likely stimulated soil enzymatic activity (Chen et al., 2005). Especially in restored lands, the vegetation cover facilitates the restoration of soil microbial status (Potthoff et al., 2006). Soil microbial properties often correlate closely with plant biomass (e.g., Spehn et al., 2000), with both aboveground and belowground inputs fueling soil food webs (Pollierer et al., 2007; Eisenhauer and Reich, 2012). Our results thus are in agreement with others studies in tropical systems where the inputs of plant litter and soil nutrients increased the soil microbial biomass and activity (Templer et al., 2005; Silva et al., 2012).

The behavior of soil microbial biomass in both degraded lands shows that when plant cover and soil organic matter are lost the soil microbial biomass and functions decrease considerably. Our results show differences between degraded lands (moderately vs. highly degraded), which may be mostly driven by the loss of plant cover and soil organic matter with level of degradation: the percentage of vegetation cover and soil organic matter content were $24 \%$ and $5.8 \mathrm{~g} \mathrm{~kg}^{-1}$ (moderately degraded land) and $4 \%$ and $2.1 \mathrm{~g} \mathrm{~kg}^{-1}$ (highly degraded land), respectively (Table 1 ). The present findings thus confirm that land degradation strongly decreases soil microbial biomass (Pascual et al., 2000; Sahani and Behera, 2001; Zhang et al., 2006). Moreover, we found that soil microbial biomass and enzymes recovered after the restoration of degraded land most likely due to the establishment of a vegetation fueling soil microorganisms with organic inputs (Grayston et al., 1996; Zhang and Fang, 2007).

Soil enzymes catalyze important biochemical transformations and indicate the effect of land degradation and restoration on soil microbial activity (De la Paz Jimenez et al., 2002; Gil-Sotres et al., 2005; Burns et al., 2013). Our results show that the soils with vegetation cover and organic matter had highest levels of enzymatic activities, while degraded soils had low enzymatic activities. In contrast to soil microbial biomass, enzymatic activities did not differ significantly between moderately and highly degraded lands, suggesting that soil enzyme activity is strongly affected by land degradation and represent a very sensitive indicator of soil disturbance.

The metabolic quotient $\left(q \mathrm{CO}_{2}\right)$ is an index used as indicator of disturbance and the carbon-use efficiency of soil microorganisms (Anderson and Domsch, 1985; Bardgett and Shine, 1999). Disturbed and inefficient soil microbial communities have high respiration in relation to their biomass and thus show high $q \mathrm{CO}_{2}$ values. In the present study land degradation caused a major disturbance of the soil microbial community and strongly increased $q \mathrm{CO}_{2}$. Inefficient carbon use efficiency in degraded soils may have been caused by the low amount of organic materials entering the soil as well as strong microclimatic fluctuations (e.g., drought, flooding) due to the lack of an intact, buffering vegetation layer. However, land restoration successfully improved the microbial metabolic status by decreasing the respiratory quotient. Our results are in accordance with a general trend where $q \mathrm{CO}_{2}$ usually declines during succession or restoration and increase during disturbance (Odum, 1997). Similarly, the ratio between microbial biomass $\mathrm{C}$ and total organic carbon was significantly lower under native vegetation and in restored land than in degraded lands. This microbial index has been used as an indicator of changes in organic matter status that occur in response to alterations in land use (Sparling, 1997), and normally the proportion of microbial biomass $C$ comprises about $1-4 \%$ of total soil organic C (Sparling, 1992) which indeed was the case in native forest and restored land. By contrast, the higher values found in degraded lands may be due to lower total organic C contents observed in these sites. Also, the values found in degraded lands were higher than $4 \%$ indicating a large proportion of organic $C$ to be found in microbial biomass, and thus may be very active and susceptible to changes (Sampaio et al., 2008).

The ratio between microbial biomass $\mathrm{C}$ and microbial biomass $\mathrm{N}$ differed significantly between restored land and all other degradation levels. This result is in contrast to the responses of the other soil microbial properties and reflects the recovery of soil microbial biomass $\mathrm{C}$, but the low levels of microbial biomass $\mathrm{N}$ in restored land. This change in microbial stoichiometry may have several not mutually exclusive reasons. First, the restoration practice applied may favor plant species with low $\mathrm{N}$ inputs to the soil. Indeed, plant communities in restored land were dominated by plants with low $\mathrm{N}$ concentrations in leaf tissue (P. maximum and $C$. juncea with $1.3 \%$ and $2 \%$ of N, respectively; Souza et al., 1999) Second, fertilization may have favored more zymogeneous soil microbial communities (Dalmonech, 2010) and caused a net $\mathrm{N}$ loss through leaching (Dijkstra et al., 2007). It is thus very likely that soil microbial community composition strongly differed between restored land and native vegetation.

Microbial biomass presents a marked seasonal cycle that differs between tropical and temperate soils (Diaz-Ravina et al., 1995). The seasonal variation in microbial biomass and enzymes activities found in our study suggests that in the wet season the soil moisture stimulated the soil microbial biomass and activity, as also observed by Silva et al. (2012) in natural and regenerated forest tropical soils. Remarkably, soil microbial communities under native vegetation and in restored land - in contrast to degraded land - showed limited fluctuations in $q \mathrm{CO}_{2}$ among the sampling dates, indicating that the soil microbial community efficiently used carbon sources despite pronounced climatic differences. This finding has important implications for restoration practices since it shows that the $\mathrm{CO}_{2}$ dynamics in soils of restored lands may be similar to that under native vegetation, indicating that land restoration may successfully prevent the loss of carbon from soils.

Plant diversity can stabilize soil processes in space (Milcu et al., 2010) and time (Proulx et al., 2010) mainly due to more continuous, higher quality plant inputs. In addition, we assumed more buffered microclimatic conditions (less extreme weather events) under native vegetation than in degraded land. We thus expected soil microbial properties under native vegetation to be more stable in time than those in degraded soils, which indeed was supported by our results. This indicates that forest soils are less subjected to environmental impacts, and that soil communities are predictable over time periods up to decades (Bengtsson, 1994). Also, Insam and Domsch (1988) evaluated the soil in two chronosequences (agriculture and forest) over time period up to 50 years and found strong variation in microbial properties with increasing time in agricultural soil, but not in forest soil. The stability of microbial properties in moderately degraded land and restored land did not differ significantly from that of native vegetation suggesting that increasing plant coverage in degraded lands may yield higher stability of soil microbial functions.

\section{Conclusions}

Land degradation strongly deteriorated soil microbial functions across years and seasons, with less efficient and stable microbial communities in degraded soils. The present study however 
indicates that land restoration practices likely are successful in promoting the fast recovery of some soil microbial functions. However, current land restoration practices may lead to significant shifts in soil microbial community composition as indicated by microbial stoichiometry in the present study. These microbial communities may be less capable of sequestering $\mathrm{N}$ with potentially significant impacts on $\mathrm{N}$ dynamics.

\section{Acknowledgments}

The authors are grateful to 'Conselho Nacional de Desenvolvimento Científico e Tecnológico' (CNPq-Brazil) for financial support of this research. Ademir S.F. Araújo, Luiz F. Leite and Siu M. Tsai are supported by Research fellowships from CNPq-Brazil (Research Productivity).

\section{Appendix A. Supplementary data}

Supplementary data related to this article can be found at http:// dx.doi.org/10.1016/j.soilbio.2013.07.013.

\section{References}

Abraham, E.M., Torres, L.M., 2007. Estado Del arte em El uso de indicadores y puntos de referencia na La lucha contra La desertificcion y La sequia em America Letina y El Caribe. INCI 32, 827-833.

Acosta-Martınez, V., Cruz, L., Sotomayor-Ramırez, D., Perez-Alegrıa, L., 2007. Enzyme activities as affected by soil properties and land use in a tropical watershed. Applied Soil Ecology 35, 35-45.

Almeida-Filho, R., Carvalho, C.M., 2010. Mapping land degradation in the Gilbues region, northeastern Brazil, using Landsat TM images. International Journal of Remote Sensing 31, 1087-1094.

Anderson, T.H., Domsch, K.H., 1985. Maintenance carbon requirements of actively metabolizing microbial populations under in situ conditions. Soil Biology \& Biochemistry 17, 197-203.

Bardgett, R.D., Shine, A., 1999. Linkages between plant litter diversity, soil microbial biomass and ecosystem function in temperate grasslands. Soil Biology and Biochemistry 31, 317-321.

Bengtsson, J., 1994. Temporal predictability in forest soil communities. Journal of Animal Ecology 63, 653-665.

Burns, R.G., 1978. Soil Enzymes. Academic Press, New York.

Burns, R.G., DeForest, J.L., Marxsen, J., Sinsabaugh, R.L., Stromberger, M.E., Wallenstein, M.D., Weintraub, M.N., Zoppini, A., 2013. Soil enzymes in a changing environment: current knowledge and future directions. Soil Biology and Biochemistry 58, 216-234.

Casida, L.E., Klein, D.A., Santoro, T., 1964. Soil dehydrogenase activity. Soil Science 98, 371-376.

Chen, C.L., Liao, M., Huang, C.Y., 2005. Effect of combined pollution by heavy metals on soil enzymatic activities in areas polluted by tailings from $\mathrm{Pb}-\mathrm{Zn}-\mathrm{Ag}$ mine. Journal of Environmental Sciences 17, 637-640.

Cooke, J.A., Johnson, M.S., 2002. Ecological restoration of land with particular reference to the mining of metals and industrial minerals: a review of theory and practice. Environmental Review 10, 41-71.

Dalmonech, D., 2010. Carbon and Nitrogen Dynamics in Forest Soils (PhD thesis). Universita Degli Studi Della Tuscia Di Viterbo, p. 165

De la Paz Jimenez, M., De la Horra, A.M., Pruzzo, L., Palma, R.M., 2002. Soil quality: a new index based on microbiological and biochemical parameters. Biology \& Fertility of Soils 35, 302-306.

Denich, M., VIelhauer, K., Kato, M.S.A., BlocK, A., Kato, O.R., Sá, T.D.A., Lucke, W., Vlek, P.L.G., 2004. Mechanized land preparation in forest-based fallow systems: the experience from Eastern Amazonia. Agroforestry System 61, 91-106.

Diaz-Ravina, M., Acea, M.J., Carballas, T., 1995. Seasonal changes in microbial biomass and nutrient flush in Forest soils. Biology \& Fertility of Soils 19, 220226.

Dijkstra, F.A., West, J.B., Hobbie, S.E., Reich, P.B., Trost, J., 2007. Plant diversity, $\mathrm{CO}_{2}$, and $\mathrm{N}$ influence inorganic and organic $\mathrm{N}$ leaching in grasslands. Ecology 88, 490-500.

Eisenhauer, N., Beßler, H., Engels, C., Gleixner, G., Habekost, M., Milcu, A., Partsch, S., Sabais, A.C.W., Scherber, C., Steinbeiß, S., Weigelt, A., Weisser, W.W., Scheu, S., 2010. Plant diversity effects on soil microorganisms support the singular hypothesis. Ecology 91, 485-496.

Eisenhauer, N., Milcu, A., Allan, E., Nitschke, N., Scherber, C., Temperton, V., Weigelt, A., Weisser, W.W., Scheu, S., 2011. Impact of above- and below-ground invertebrates on temporal and spatial stability of grassland of different diversity. Journal of Ecology 99, 572-582.

Eisenhauer, N., Milcu, A., Sabais, A.C.W., Bessler, H., Weigelt, A., Engels, C., Scheu, S., 2009. Plant community impacts on the structure of earthworm communities depend on season and change with time. Soil Biology and Biochemistry 41, 2430-2443.

Eisenhauer, N., Reich, P.B., 2012. Above- and below-ground plant inputs both fuel soil food webs. Soil Biology and Biochemistry 45, 156-160.

Embrapa, 1986. Levantamento exploratório - reconhecimento de solos do Estado do Piauí. Serviço Nacional de Levantamento e Conservação de Solos. 2v. In: EMBRAPA-SNLCS. Boletim de Pesquisa, 36. Brasil. SUDENE-DRN Série Recursos de Solos, 18. Rio de Janeiro, Brasil.

Freire, J.L., Dubeux Júnior, J.C.B., Lira, M.A., Ferreira, R.L.C., Santos, M.V.F. Freitas, E.V., 2010. Litter deposition and chemical composition under a Mimosa canopy. Revista Brasiliera de Zootecnia 39, 1650-1658.

Gil-Sotres, F., Trasar-Cepeda, C., Leiros, M.C., Seoane, S., 2005. Different approaches to evaluating soil quality using biochemical properties. Soil Biology \& Biochemistry 37, 877-887.

Grayston, S.J., Vaughan, D., Jones, D., 1996. Rhizosphere carbon flow in trees, in comparison with annual plants: the importance of root exudation and its impact on microbial activity and nutrient availability. Applied Soil Ecology 5, 29-56.

Hackl, E., Bachmann, G., Zechmeister-Boltenstern, S., 2004. Microbial nitrogen turnover in soils under different types of natural forest. Forest Ecology \& Management 188, 101-112.

Insam, H., Domsch, K.H., 1988. Relationship between soil organic carbon and microbial biomass chronosequences of reclamation sites. Microbial Ecology 15, 177-188.

Jenkinson, D.S., Ladd, J.N., 1981. Microbial biomass: measurement and turnover. In: Paul, E.A., Ladd, J.N. (Eds.), Soil Biochemistry, vol. 5. Marcel Deckker, New York, pp. 415-471.

Lal, R., 1996. Deforestation and land-use effects on soil degradation and rehabilitation in western Nigeria: soil chemical properties. Land Degradation \& Development 7, 87-98.

Lopes, E.L.N., Fernandes, A.R., Ruivo, M.L.P., Cattanio, J.H., Souza, G.F., 2011. Microbial biomass and soil chemical properties under different land use systems in northeastern Pará. Revista Brasileira de Ciencia do Solo 35, 1127-1139.

Milcu, A., Thebault, E., Scheu, S., Eisenhauer, N., 2010. Plant diversity enhances the reliability of belowground processes. Soil Biology \& Biochemistry 42, 21022110.

Nsabimana, D., Haynes, R.J., Wallis, F.M., 2004. Size, activity and catabolic diversity of the soil microbial biomass as affected by land use. Applied Soil Ecology 26, 81-92.

Nunes, J.S., Araújo, A.S.F., Nunes, L.A.P.L., Lima, L.M., Carneiro, R.F.V., Tsai, S.M. Salviano, A.A.C., 2012. Land degradation on soil microbial biomass and activity in Northeast Brazil. Pedosphere 22, 88-95.

Odum, E.P., 1997. Ecology: a Bridge Between Science and Society. Sinauer Associates, Sunderland, MA.

Paiva, A.O., Rezende, A.V., Pereira, R.S., 2011. Carbon stock in cerrado sensu stricto in the Federal District. Revista Árvore 35, 527-538.

Pascual, J.A., Hernandez, C.G.T., Moreno, J.L., Ros, M., 2000. Soil microbial activity as a biomarker of degradation and remediation processes. Soil Biology \& Biochemistry 32, 1877-1883.

Pollierer, M.M., Langel, R., Körner, C., Maraun, M., Scheu, S., 2007. The underestimated importance of belowground carbon input for forest soil animal food webs. Ecology Letters 10, 729-736.

Potthoff, M., Steenwerth, K.L., Jackson, L.A., Drenovsky, R.E., Scow, K.M. Joergensen, R.G., 2006. Soil microbial community composition as affected by restoration practices in California grassland. Soil Biology \& Biochemistry 38, 1851-1860.

Powlson, D.S., Brookes, P.C., Christensen, B.T., 1987. Measurement of soil microbial biomass provides an early indication of changes in total soil organic matter due to straw incorporation. Soil Biology \& Biochemistry 19, 159-164.

Proulx, R., Wirth, C., Voigt, W., Weigelt, A., Roscher, C., Attinger, S., Baade, J., Barnard, R.L., Buchmann, N., Buscot, F., Eisenhauer, N., Fischer, M., Gleixner, G. Halle, S., Hildebrandt, A., Kowalski, E., Kuu, A., Lange, M., Milcu, A., Niklaus, P.A Oelmann, Y., Rosenkranz, S., Sabais, A.C.W., Scherber, C., Scherer-Lorenzen, M. Scheu, S., Schulze, E.-D., Schumacher, J., Schwichtenberg, G., Soussana, J.-F., Temperton, V., Weisser, W.W., Wilcke, W., Schmid, B., 2010. Diversity promotes temporal stability across levels of ecosystem organization in experimental grasslands. PLoS ONE 5, e13382.

Sahani, U., Behera, N., 2001. Impact of deforestation on soil physicochemical characteristics, microbial biomass and microbial activity of tropical soil. Land Degradation \& Development 12, 93-105.

Sampaio, D.B., Araújo, A.S.F., Santos, V.B., 2008. Avaliação de indicadores biológicos de qualidade do solo sob sistemas de cultivo convencional e orgânico de frutas. Ciencia e Agrotecnologia 32, 353-359.

Santos, V.B., Araújo, A.S.F., Leite, L.F.C., Nunes, L.A.P.L., Melo, W.J., 2012. Soil microbial biomass and organic matter fractions during transition from conventional to organic farming systems. Geoderma 170, 227-231.

Scheiner, S.M., Gurevitch, J., 2001. Design and Analysis of Ecological Experiments, second ed. Oxford University Press, New York, USA.

Schinner, F., von Mersi, W., 1990. Xylanase, CM-cellulase and invertase activity in soil: an improved method. Soil Biology and Biochemistry 22, 511-515.

Schnurer, J., Rosswall, T., 1982. Fluorescein diacetate hydrolysis as a measure of total microbial activity in soil and litter. Applied Environmental Microbiology 43 , 1256-1261.

Secretaria do Meio Ambiente e Recursos Hídricos - SEMAR, 2010. Combate a desertificação no Piauí. EDUFPI, p. 223. 
Silva, D.K.A., Freitas, N.O., Sousa, R.G., Silva, F.S.B., Araújo, A.S.F., Maia, L.C., 2012. Soil microbial biomass and activity under natural and regenerated forests and conventional sugarcane plantations in Brazil. Geoderma 189, 257-261.

Souza, L.S., Velini, E.D., Maimoni-Rodella, R.C.S., Martins, D., 1999. Contents of macronutrients and micronutrients and $\mathrm{CN}$ relation of several weed species. Planta Daninha 17, 163-167.

Sparling, G.P., 1992. Ratio of microbial biomass carbon to soil organic carbon as a sensitive indicator of changes in soil organic matter. Australian Journal of Soil Research 30, 195-207.

Sparling, G.P., 1997. Soil microbial biomass, activity and nutrient cycling as indicators of soil health. In: Pankhurst, C., Doube, B.M., Gupta, V.V.S.R. (Eds.) Biological Indicators of Soil Health. CAB International, Cambridge, pp. 97-120.

Spehn, E.M., Joshi, J., Schmid, B., Alphei, J., Körner, C., 2000. Plant diversity effects on soil heterotrophic activity in experimental grassland ecosystems. Plant and Soil 224, 217-230.

Tedesco, M.J., Gianello, C., Bissani, C.A., 1995. Analises de solos, plantas e outros materiais. UFRGS, Porto Alegre.

Templer, P.H., Groffman, P.M., Flecker, A.S., Power, A.G., 2005. Land use change and soil nutrient transformations in the Los Haitises region of the Dominican Republic. Soil Biology \& Biochemistry 37, 215-225.

Van der Heijden, M.G.A., Bardgett, R.D., van Straalen, N.M., 2008. The unseen majority: soil microbes as drivers of plant diversity and productivity in terrestrial ecosystems. Ecology Letters 11, 296-310.
Vance, E.D., Brookes, P.C., Jenkinson, D.S., 1987. An extraction method for measuring soil microbial biomass C. Soil Biology \& Biochemistry 19, 703-707.

Veloso, M.E.C., Leite, L.F.C., Araujo, E.C.E., Rocha Junior, A.F., Lima, M.G., Salviano, A.A.C., 2010. Soil structure analyses and water infiltration under degraded area, Gilbués, PI. In: International Conference: Climate, Sustainability and Development in Semiarid Regions. Fortaleza, pp. 1-4

Veras, V.S., Oliveira, M.E., Lacerda, M.S.B., Carvalho, T.B., Alves, A.A., 2010. Biomass production and pasture structure of Andropogon grass in a silvopastoral system and in monoculture. Arquivos Brasileiros de Medicina Veterinaria e Zootecnia 62, 200-207.

Yeomans, J.C., Bremner, J.M., 1998. A rapid and precise method for routine determination of organic carbon in soil. Communications in Soil Science Plant Analysis 19, 1467-1476.

Zak, D.R., Holmes, W.E., White, D.C., Peacock, A.D., Tilman, D., 2003. Plant diversity, soil microbial communities and ecosystem function: are there any links? Ecology 84, 2042-2050.

Zhang, M., Fang, L., 2007. Effect of tillage, fertilizer and green manure cropping on soil quality at an abandoned brick making site. Soil Tillage Research 93, 87-93.

Zhang, P., Li, L., Pan, G., Ren, J., 2006. Soil quality changes in land degradation as indicated by soil chemical, biochemical and microbiological properties in a karst area of southwest Guizhou, China. Environmental Geology 51, 609-619.

Zimmermann, S., Frey, B., 2002. Soil respiration and microbial properties in an acid forest soil: effects of wood ash. Soil Biology \& Biochemistry 34, 1727-1737. 